Arch. Tierz., Dummerstorf 46 (2003) 6, 585-595

Kaposvár University, Faculty of Animal Science, Hungary

GABRIELLA ANDRÁSSY-BAKA, RÓBERT ROMVÁRI, GÁBOR MILISITS, ZOLTÁN SÜTÖ, ANDRÁS SZABÓ, LÀSZLÓ LOCSMÁNDI and PETER HORN

\title{
Non-invasive body composition measurement of broiler chickens between 4 - 18 weeks of age by computer tomography
}

\begin{abstract}
Non-invasive computerized tomography was performed on commercial broiler chickens, in both sexes, between 4 to 18 weeks of age, with the aim of body composition measurement. On the basis of 16-32 scans gathered from each bird during the scanning procedure, volumetric measurement of the breast muscle was performed. These values were at the $259 ; 493 ; 786 \mathrm{~cm}^{3}$ and $195 ; 460 ; 668 \mathrm{~cm}^{3}$ in male and female birds at the age of 6,12 and 18 weeks, respectively. The total body fat content was characterized by the so called ,fat index”, a value independent of the live weight. This indices were 7,3;7,14;9,48 and 8,8;13,3;21,6 following the above order. Total body fat and crude protein was determined both by CT and chemical analysis. The variables of the prediction equations were taken from the density values of the Hounsfield scale between -140 and +150 , by summarizing the frequencies within each interval of 10 values. Several models were developed with Principal Component Analysis. The $\mathrm{R}^{2}$ values of the estimations were high $\left(\mathrm{R}^{2}=0,89 ; 0,88\right)$ for total body fat but moderate $\left(\mathrm{R}^{2}=0,39 ; 0,44\right)$ in the prediction of crude protein content. The investigation of the tissue development in the body was carried out by means of 3D histograms.
\end{abstract}

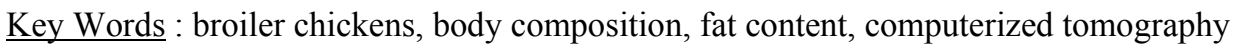

\section{Zusammenfassung}

Titel der Arbeit: Lebendmessung der Körperzusammensetzung von Broilerküken im Alter von 4-18 Wochen mittels Computer Tomographie

Die Ermittlung der Körperzusammensetzung von Broilerküken beiderlei Geschlechts im Alter von 4-18 Wochen erfolgte mittels nicht invasiver Computertomographie. Die volumetrische Bestimmung der Brustmuskulatur erfolgte auf der Basis der von allen Tieren angefertigten 16-30 Bilder. Die für männliche und weibliche Tiere ermittelten Werte im Alter von 4, 6 und 18 Wochen betrugen 259, 493 und786 cm bzw. 195, 460 und $668 \mathrm{~cm}^{3}$. Der Fettgehalt der Ganzkörper wurde mit Hilfe des sogenannten „Fettindexes“ geschätzt da dieser unabhängig vom Körpergewicht ist. Er lag entsprechend der vorherigen Reihenfolge bei 7,30, 7,14 und 9,48 bzw. 8,80, 13,3 und 21,60. Der Protein- und Fettgehalt der Tierkörper wurde nicht nur mittels der Computertomographie erfasst, sondern auch durch chemische Analysen bestimmt. Die Variablen der Schätzungsgleichungen stammten von den Densitätswerten zwischen -140 und +150 auf der Hounsfield Skala, nach dem jeweils 10 Freqenzwerte zusammengefasst wurden. Mit Hilfe der Hauptkomponentenanalyse wurden mehrere Modelle verglichen. Die $\mathrm{R}^{2}$ Schätzungen ergaben beim Ganzkörperfett relativ hohe Werte von $\mathrm{R}^{2}=0,89$ bzw. 0,98 und für den Proteinanteil mittlere Werte von $\mathrm{R}^{2}=0,39$ bzw. 0,44. Die Gewebeentwicklung wurde mit Hilfe von 3D Histogrammen bewertet.

Schlüsselwörter: Broiler, Körperzusammensetzung Fettgehalt, Proteingehalt, Computer Tomographie

\section{Introduction}

Remarkable changes have taken place in body conformation and composition of meat type chickens in the past 50 years. While in 1950 a 12 weeks period was required to reach the slaughter weight of $1.8-2.0 \mathrm{~kg}$, nowadays it takes less than the half of it. According to HAVENSTEIN and FERKET (2002), the effects of both genetics and 
nutrition resulted in a body weight increase of approximately 31 to 99 g/year at 42 and 84 days, respectively, during the last decade. However, the performance limitations are unknown, though prognosis is available (SAVORY, 2002). On the other hand, parallel with the well known reduction of market age, only a few data is available for broilers raised far over normal broiler or roaster age. The Ross 1. broiler strain was examined until 364 days of age by GREY et al. (1982). The growth and chemical composition of experimental lines was studied by SØRENSEN and DUCRO (1995). HANCOCK et al. (1995) characterized the growth rate of commercial genotypes until 26 weeks of age by Gompertz growth equations.

When studying the composition of growing chickens, it is often necessary to measure whole body composition. However, there is a lack of information in the literature, possibly due to the difficulties of adequate body homogenization. In reports on the a long term (20 week) fattening trial of broiler chickens (HORN et al., 1998; SÜTÖ et al., 1998), the carcass traits, abdominal fat deposition and chemical composition were studied. In addition, some in vivo MRI investigations were carried out on a limited number of animals, to predict the breast muscle, abdominal fat- and total fat volume (KÖVÉR et al., 1998). This MRI method can effectively complement the computerized tomography (CT) scanning in the transversal plane.

In the current study parallel to the above-mentioned examinations in vivo CT imaging procedure was applied. Similar methods were used by BENTSEN and SEHESTED (1989) and SVIHUS and KATLE (1993) and ROMVÁRI et al. (1994) for the determination of the abdominal fat amount and the breast muscle weight of broiler chickens. In regard of breast muscles comparative HRCT investigation of different broiler genotypes was performed and also complemented with 3D reconstruction by ROMVÁRI et al. (2000). Dual X-ray absorptiometry was applied by MITCHELL et al. (1998) for the body composition analysis of growing broiler chickens.

\section{Materials and Methods}

\section{Animals}

A total of 144 Arbor Acress Regular meat type chickens were used. All birds selected for CT examination each time had to be within a 3\% range deviation from the mean live weight of the population; sexes were treated separately. Six birds by sex were taken for scanning at the age 4, 5, 6, 7, 8, 9, 10, 12, 14, 16, and 18 weeks. Birds were raised in a closed, air-conditioned building on deep litter at the Test Station of the Kaposvár University, Faculty of Animal Science. The managemental procedures applied during the 20 week growing period was described in detail by HORN et al. (1998).

\section{CT procedure and data processing}

The CT images were taken by means of a Siemens Somatom DRG scanner of the Institute of Diagnostic Imaging and Radiation Oncology, after 8 hours of feed withdrawal. Chickens, three at the same time, were fixed in stretched position with belts, in a specially designed holder, without using anaesthetics. The examinations started with the taking up an overall topogram, which is similar to a conventional two dimensional X-ray picture. In the topogram the anatomical locations of the crosssectional scans or body intervals can be marked. Depending on the size of the birds 16 to 32 overlapping scans of $8 \mathrm{~mm}$ scan thickness were taken, covering the whole body 
(Figure 1 and 2). To equalize the size difference and to reduce the amount of raw data, altogether 16 identical anatomic locations (IAL) were chosen.
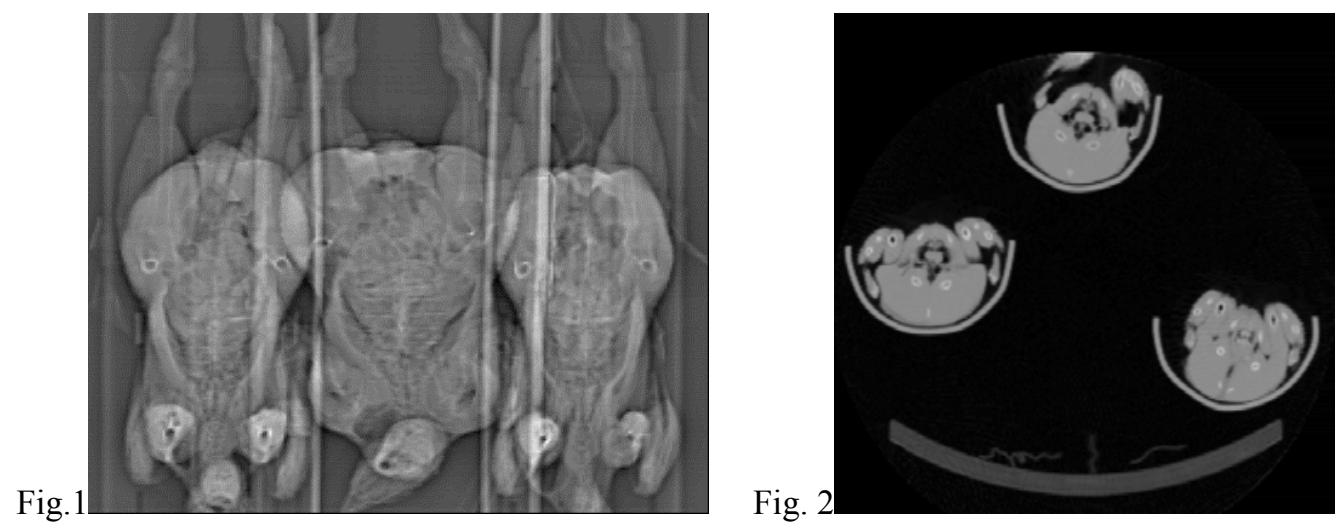

Fig. 1 and 2: Two dimensional topogram of three birds and the cross sectional image made at the anatomical point at the and of the clavicle (Zweidimensionales Topogramm von drei Tieren und Querschnittsflächen bei der anatomischen Position am Ende des Clavicula)

The picture-forming pixels of CT images are in fact small prisms with definite volume. It is possible, therefore, to determine the part of the total volume of the examined scan that falls into the Hounsfield unit (HU) interval of interest. On this basis the estimation of fat tissue volume of the body was possible, from the serial scans. Pixel density data were collected from by excluding the extreme density values (corresponding to bone or air); only those corresponding to muscle and fat were retained, i.e. the range from 200 to 200 on the Hounsfield scale (fluid water $=0$ ). Each consecutive $10 \mathrm{HU}$ values were summarized, resulting altogether in 40 Hounsfield variables (HUv).

\section{Slaughtering and chemical analysis}

The birds were slaughtered following a 12-hour fasting period. The breast muscle was weighed and after removal of the alimentary tract content, the rest of the broiler (empty body) was homogenized and used for chemical analysis, according to SÜTÖ et al. (1998). Dry matter (DM) was determined by drying the sample at $105{ }^{\circ} \mathrm{C}$ to constant weight. Crude fat (CF) was weighed after ether extraction. Hydrochloride acid digestion and Kjel-Foss Fast Nitrogen Analyzer was used for the determination of the nitrogen content, which was converted to crude protein $(\mathrm{CP})$ by multiplying with 6.25 .

\section{Statistical methods}

The data arising from the sixteen intervals (representing IAL) were used for the graphical demonstration of the body composition. Based on the 40 Hounsfield variables 3D histograms were developed with negative exponential interpolation - at the age of 6,12 and 18 weeks, in both sexes - to characterize the fat and muscle tissue development inside the body.

In order to examine the fat content of the chickens in different ages, "fat indices" were created from all the CT images, by relating pixels corresponding to fat densities to the total number of pixels according to the formula: ( $\sum$ HUv6-12/ $\sum$ HUv1-40) x 100 (ROMVÁRI et al., 1998). To test the predictive value of these indices, regression 
analysis (SPSS FOR WINDOWS 10, 1999) was performed between the fat indices and the chemically determined fat content (CF) of the body.

Furthermore, the birds were divided into two groups of 94 and 47, randomly. The accuracy of the estimated parameters of the prediction equations developed on the first group, was tested on the second group. In the further data processing, for the calculation of prediction equations, the number of variables, arising from the 16 IAL, was reduced to $31 \mathrm{HUv}$ ( $\mathrm{HU}-170$ to 140 ) from the initial 40, without any information loss, taken into account that the interval excluded falls outside that, characteristic for fat and muscle tissue, in broilers. Factor analysis with varimax rotation was applied (SPSS for Windows 10, 1999) to decrease the multi-co-linearity of the neighbouring HU variables. The principal components (PC) were calculated first from the HU variables of the total body, than from the abdominal part (5., 6. and 7. anatomic location, AL). Prediction equations were developed by linear regression using stepwise method to select the appropriate independent variables from the previously calculated principal components or factors.

\section{Results}

The average live weight data of the highlighted age categories can be seen in Table 1 . The measured values agree with those published by SÜTÖ et al. (1998).

Table 1

Characteristic live weight, tissue- and chemical composition data ( $\mathrm{n}=6$ per sex and age) (Lebendgewicht, Gewebe- und chemische Zusammensetzung der untersuchten Tiere ( $\mathrm{n}=6$ je Geschlecht))

\begin{tabular}{|c|c|c|c|c|c|c|}
\hline \multirow{3}{*}{ Males } & \multicolumn{6}{|c|}{ Weeks } \\
\hline & \multicolumn{2}{|c|}{6} & \multicolumn{2}{|c|}{12} & \multicolumn{2}{|c|}{18} \\
\hline & Ave & SD & Ave & SD & Ave & SD \\
\hline $\begin{array}{c}\text { Liveweight } \\
\text { (g) }\end{array}$ & 1741 & 41.2 & 3473 & 65.3 & 5216 & 121.1 \\
\hline $\begin{array}{l}\text { Abdominal Fat } \\
(\mathrm{g})\end{array}$ & 15.7 & 5.47 & 37.2 & 12.4 & 112 & 38.1 \\
\hline $\begin{array}{c}\text { Crude Fat } \\
(\%)\end{array}$ & 10.3 & 2.24 & 12.7 & 2.38 & 15.2 & 1.02 \\
\hline Fat Index & 0.07 & 0.01 & 0.07 & 0.01 & 0.09 & 0.02 \\
\hline $\begin{array}{l}\text { Breast Volume } \\
\left(\mathrm{cm}^{3}\right)\end{array}$ & 259 & 16.3 & 493 & 18.1 & 786 & 121 \\
\hline \multicolumn{7}{|l|}{ Females } \\
\hline $\begin{array}{l}\text { Liveweight } \\
(\mathrm{g})\end{array}$ & 1458 & 42.2 & 2933 & 64.1 & 4096 & 95.0 \\
\hline $\begin{array}{l}\text { Abdominal Fat } \\
(\mathrm{g})\end{array}$ & 18.3 & 4.08 & 51.5 & 41.9 & 235 & 58.6 \\
\hline $\begin{array}{c}\text { Crude Fat } \\
(\%)\end{array}$ & 11.9 & 1.52 & 20.2 & 3.06 & 27.8 & 4.73 \\
\hline Fat Index & 0.08 & 0.01 & 0.13 & 0.02 & 0.21 & 0.04 \\
\hline $\begin{array}{l}\text { Breast Volume } \\
\quad\left(\mathrm{cm}^{3}\right)\end{array}$ & 195 & 11.9 & 460 & 25.0 & 668 & 48.9 \\
\hline
\end{tabular}

The changes of tissue composition were depicted at the age of 6,12 and 18 weeks of age in both sexes. Figure 2 and 8 are 3D histograms, constructed from the data of the 
chicken groups at the age of 6 weeks. The serial number of the pictures was illustrated on the $\mathrm{X}$-axis, the $\mathrm{HU}$ variables on the $\mathrm{Y}$-axis (numbering from 40 to 1 after reducing by 10 from +200 to -200 ) and the frequency of the density values on the Z-axis. For the comparability of the histograms prepared at different ages identical scaling was used.

In case of 6-week-old animals, in the protrusion formed by the muscle tissue interval (HUv 21-40) two characteristic peaks are clearly to be recognized. The first from the head is the peripheral region of the breast muscle (2-6). The next, something lower part is the pelvic interval, after which the highest "peak", formed by the drumsticks and the thighs can be seen (9-15). The thigh musculature of males highly exceeded that of females at the age of 6 weeks (Figure 3 and 4).

Male

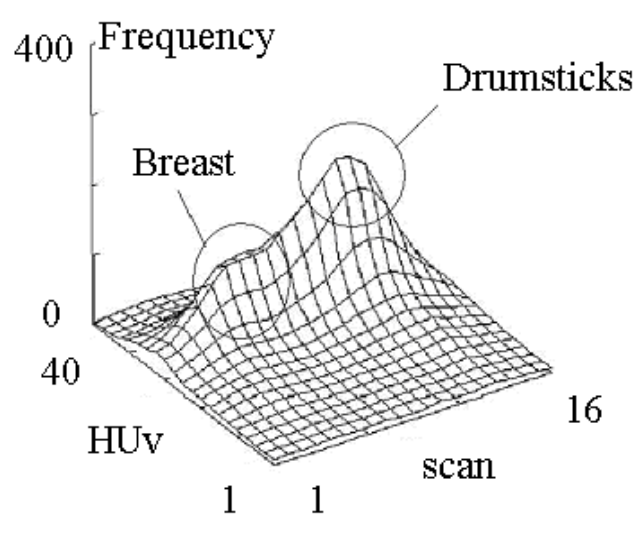

Female

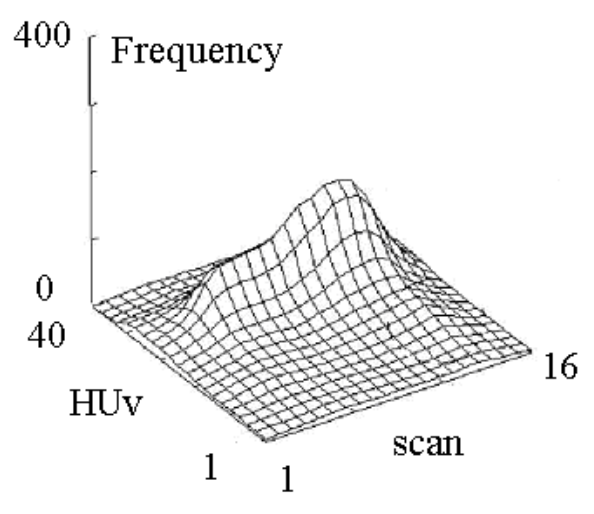

Fig. 3 and 4: 3D histograms at the age of 6 weeks of the male and female chickens (3D Histogramme von 6 Wochen alten männlichen und weiblichen Tieren)

At 12 weeks of age, two marked differences can be seen between the two sexes (Figure 4 and 5). A higher abdominal fat (HUv 6-12) content appeared in the females and, at the same time, the larger muscle peek corresponding the thigh, is clearly visible.
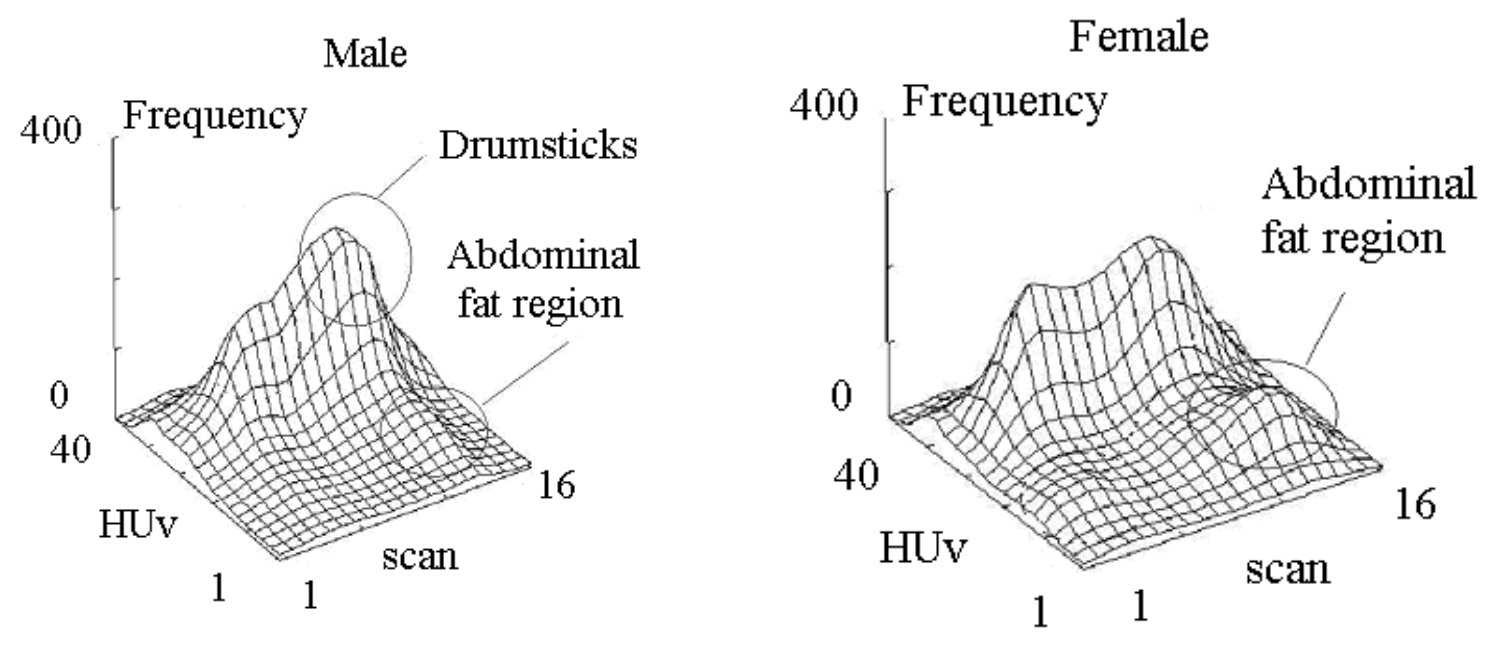

Fig. 4 and 5: 3D histograms at the age of 12 weeks of the male and female chickens (3D Histogramme von 12 Wochen alten männlichen und weiblichen Tieren) 
At the end, the last members of the series represent a 20-weeks-old category (Figure 6 and 7). Here, compared to previous categories, the amount of the fat increases significantly. The abdominal fat depot (12 - 16 scans) can especially be precisely identified, and the fatness of the neck part is quite significant, also in females. In addition, a large drumstick-thight peek distinguished the males from females at this time.
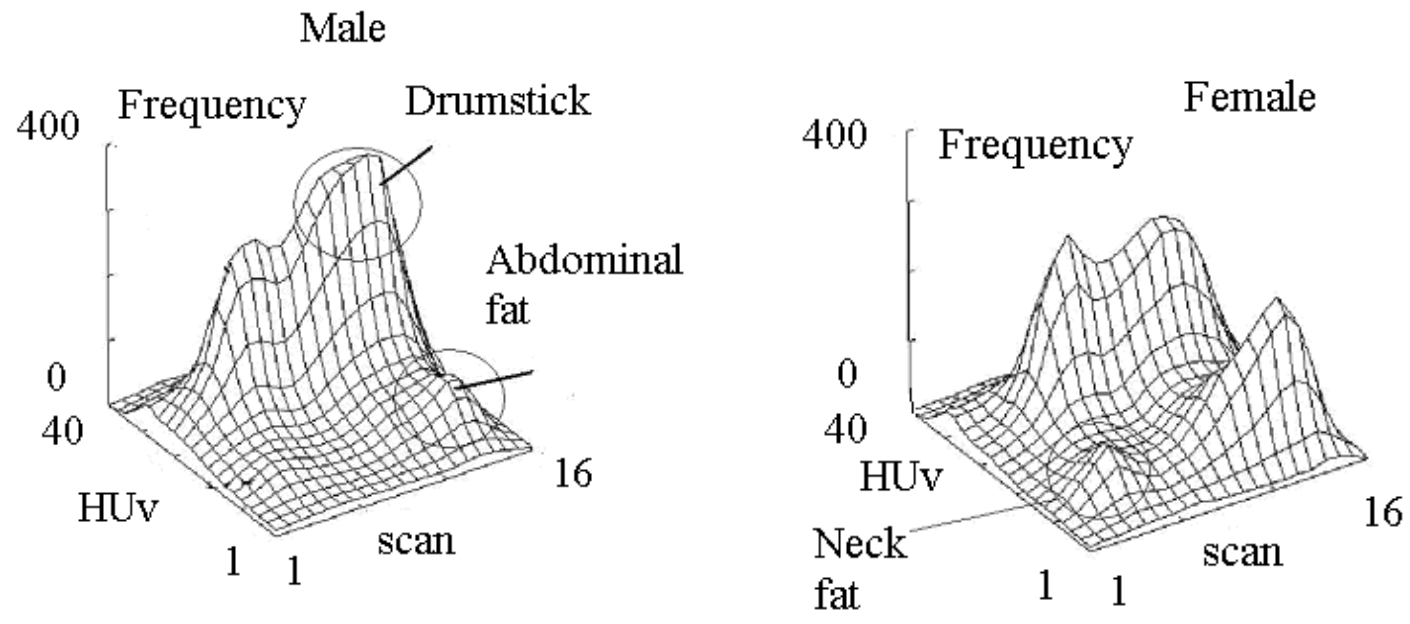

Fig. 6 and 7: 3D histograms at the age of 18 weeks of the male and female chickens (3D Histogramme von 18 Wochen alten männlichen und weiblichen Tieren)

Differences of two histograms prepared between the $12^{\text {th }}$ and $18^{\text {th }}$ weeks demonstrated that mainly the thigh muscle deposition increased continuously in male while the fat deposition especially in the region of the abdominal fat was considerably larger in female than the male broilers (Figure 8 and 9).

Male

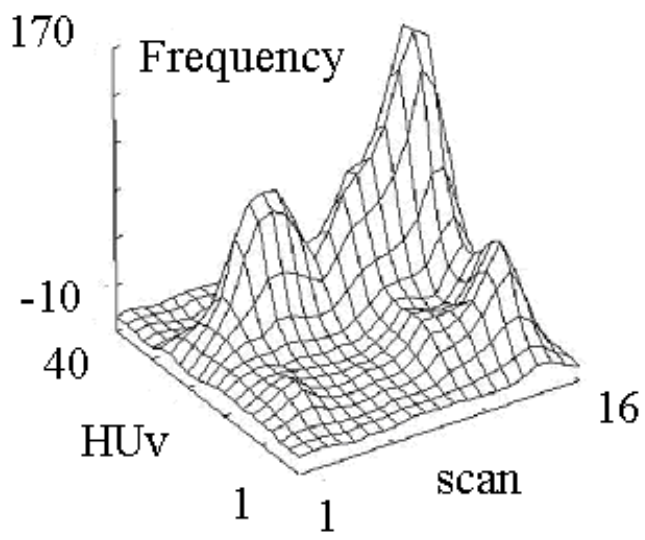

Female

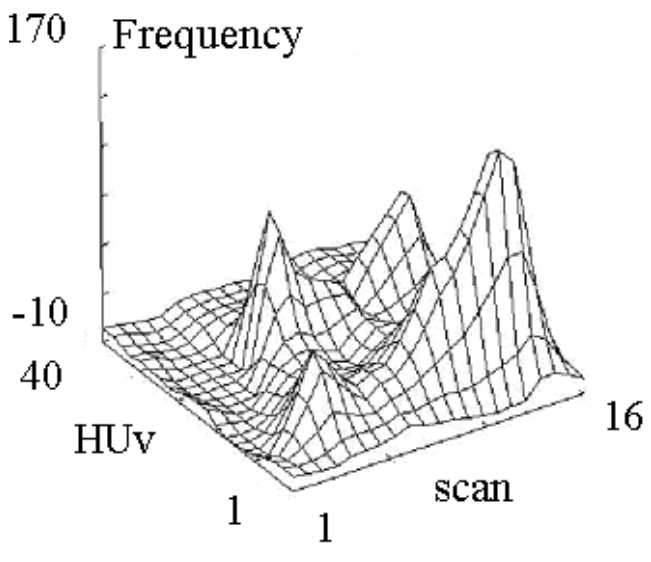

Fig. 8 and 9: 3D histograms of changes of the body composition between 12 and 18 weeks of age of the male and female chickens (3D Histogramme von Veränderungen der Körperzusammensetzung zwischen 12. und 18. Lebenswoche bei männlichen und weiblichen Tieren)

Three age categories were characterized by means of serial-scan based 3D histograms, during the 18-week raising period. The muscle development of males clearly exceeded that of females, at every age investigated. This was matched with a stronger abdominal fat deposition in females. The histograms, created from the tissue-specific density 
distributions, when compared to the results of the experimental slaughtering, proved to be suitable for the investigation of tissue development at pre-defined anatomical locations.

The fat content of the chicken body was first estimated with direct volumetry. There were no changes in the characteristic X-ray density values of muscle and fat tissues in the investigated live weight intervals. For this reason, in the CT images of broilers of different size, pixels with the same numeric value (Hu value) indicate identical tissue types. Figure 10 shows the relationship between the CF content and the fat index, calculated from all the scans of the chickens $\left(\mathrm{R}^{2}=0.895, \mathrm{P}<0.05\right)$.

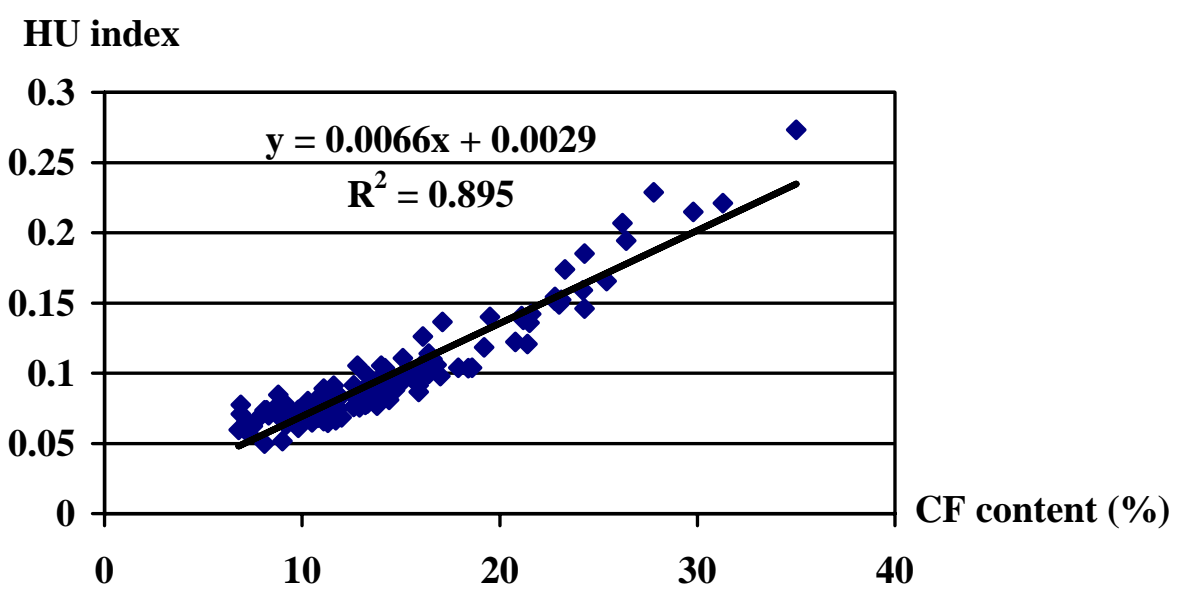

Fig. 10: Relationship between the HU index calculated from all images and the CF content (Beziehung zwischen HU Index aller CT-Bilder und dem Rohfettgehalt)

Moreover, prediction equations were developed. The reliability of the CF prediction may be decreased by the relatively strong linear connection between the neighbouring HU values [e.g. HU9 $=(-120)-(-111)$, HU10 $=(-110)-(-101)]$. With the applied principal component (PC) analysis, this effect has been diminished, by finding linear combinations of the variables explaining most of the variability. Table 2 includes different number of PCs with the eigenvalue greater than 1, originating first from the total body, than from the abdominal region.

PCs of eigenvalue higher than 1 were determined, first on the basis of the summarized density distributions arising from the total body, then the same procedure was performed on the 8 body intervals. This resulted in 3 and $6 \mathrm{PCs}$, respectively, calculated from 93 and 248 original variables (AL1, AL2, AL8. - 8 x 31 HU variables $\rightarrow 6$ Pc (F1, F2... F6)

Table 2

Principal components explaining the variance (\%) of the original HU variables (Hauptkomponenten, die für den Varianzanteil (\%) der originalen HU Indexe verantwortlich sind)

\begin{tabular}{ccc}
\hline Factor no. & \% of total variance & AL8 \\
& Total body & 30,2 \\
1 & 81,3 & 25,3 \\
2 & 11,2 & 16 \\
3 & 3,1 & 1,5 \\
4 & & 4,9 \\
5 & & 4,6 \\
6
\end{tabular}


The first two equations were constructed from the 3 PCs originating from the total body with the MGLH procedure (Table 3). While Eq1 contained the live weight as an independent variable, Eq2, developed by stepwise regression, did not.

Table 3

Basic data of the prediction equations Eq1 and Eq2 (Grunddaten der Schätzungsformeln Eq1 und Eq2)

\begin{tabular}{|c|c|c|c|c|c|}
\hline Eq 1 & & $\mathrm{R}^{2}=0.89$ & Eq 2 & & $\mathrm{R}^{2}=0.88$ \\
\hline & & $\mathrm{SEE}=2.01$ & & & $\mathrm{SEE}=2.04$ \\
\hline Variable & $\mathrm{B}$ & Sig. T & Variable & $\mathrm{B}$ & Sig. T \\
\hline FAC1 & 3,450 & 0,005 & FAC1 & & 0,000 \\
\hline FAC2 & 7,184 & 0,000 & FAC2 & & 0,000 \\
\hline FAC3 & 1,520 & 0,053 & & & \\
\hline liveweight & $-0,00308$ & 0,039 & & & \\
\hline Constant & 21.991 & 0,000 & Constant & 14.305 & 0,000 \\
\hline
\end{tabular}

More equations (Eq3 and Eq4) were developed analogously, based on the 6 PCs from the abdominal region (Table 4). In this case, the accuracy of the relationship was not reduced, indicating that the total body fat content can effectively be characterized by the abdominal fat amount.

Table 4

Basic data of the prediction equations Eq3 and Eq4 (Grunddaten der Schätzungsformeln Eq3 und Eq4)

\begin{tabular}{|c|c|c|c|c|c|}
\hline \multirow[t]{2}{*}{ Eq 3} & \multicolumn{2}{|r|}{$\mathrm{R}^{2}=0.88$} & \multicolumn{2}{|l|}{ Eq 4} & $\mathrm{R}^{2}=0.86$ \\
\hline & & $\mathrm{SEE}=2.12$ & & & $\mathrm{EE}=2.26$ \\
\hline Variable & B & Sig. T & Variable & B & Sig. T \\
\hline FAC1 & 6,768 & 0,000 & FAC1 & 5,232 & 0,000 \\
\hline FAC2 & 2,671 & 0,000 & FAC6 & 1,118 & 0,000 \\
\hline FAC3 & 1,699 & 0,000 & FAC5 & 0,964 & 0,000 \\
\hline FAC4 & 1,398 & 0,001 & FAC2 & 0,771 & 0,000 \\
\hline FAC5 & 1,516 & 0,000 & & & \\
\hline FAC5 & 1,414 & 0,000 & & & \\
\hline liveweight & $-0,00253$ & 0,000 & & & \\
\hline Constant & 21.552 & 0,000 & Constant & 14.436 & 0,001 \\
\hline
\end{tabular}

where $y=$ fat content of "empty body" (\%); F1, F2 ..F5 = principal components; B = regression coefficient; Sig. T = significance level.

More attempts were made to predict the CP content in both sexes, in the same way. Similarly to our earlier results in rabbits (ROMVÁRI et al., 1998), the $\mathrm{R}^{2}$ values ranged between 0.39 and 0.44 , depending on the model developed. These low to medium correlation values seem to be too inaccurate for the prediction of crude protein.

The prediction equations for the total body fat content were tested on the dataset obtained from the CT scanning of the second group of 47 broilers (both groups being totally indentical). Equations Eq1. and Eq2.were based on the total body CT dataset. When testing the above-mentioned equations on the second 47 broilers, the 
relationship was slightly weaker $\left(\mathrm{Eq} 1 \mathrm{R}^{2}=0,89\right.$, and 0,$82 ; \mathrm{Eq} 2 \mathrm{R}^{2}=0.88$, and 0.81$)$ (Figure 11).

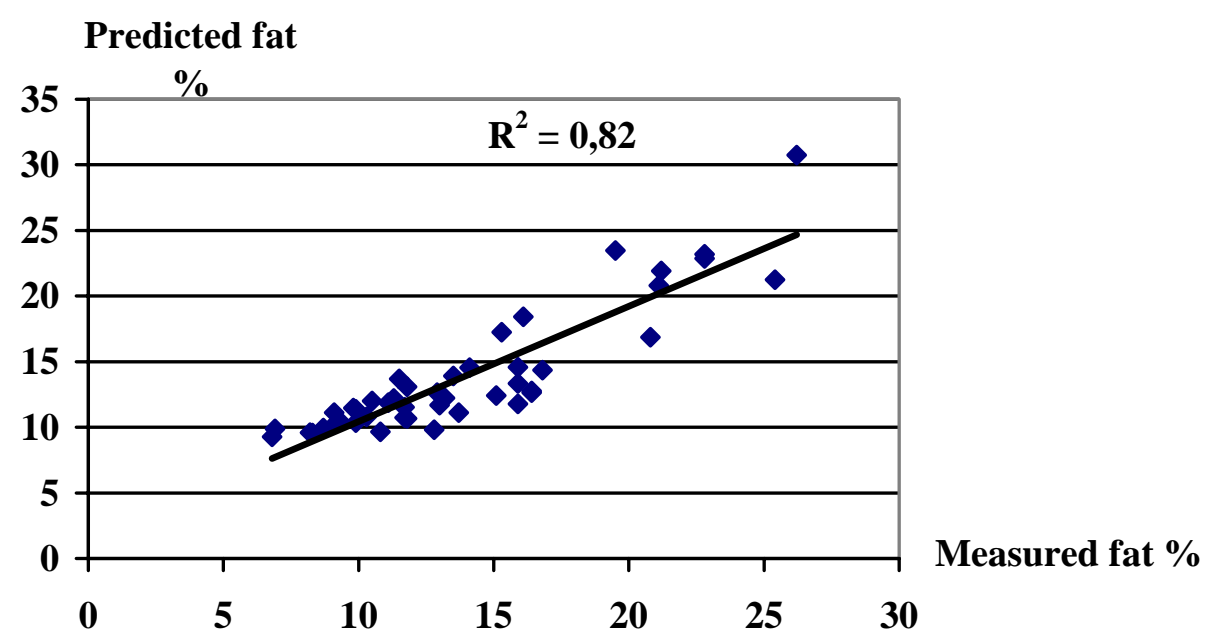

Fig. 11. Correlation between the predicted and the measured fat content $(\%)$ of chickens as determined by principal component analysis (Eq1 based on total body) (Korrelation zwischen dem erfaßten (\%) und mit Hilfe der Hauptkomponentenanalyse (Eq1 vom Ganzkörper) geschätzten Fettgehalt der Tiere)

The prediction using Eq3 and Eq4 was based on the abdominal region. Interestingly, the relationship in case of the groups used for testing was only less loose (Eq3 $\mathrm{R}^{2}=0.88$, and $0.84 ; \mathrm{Eq} 4 \mathrm{R}^{2}=0.86$, and 0.83 , respectively). In the verification course of prediction equations those obtained from the abdominal region were found to be more precise for $\mathrm{CF}$.

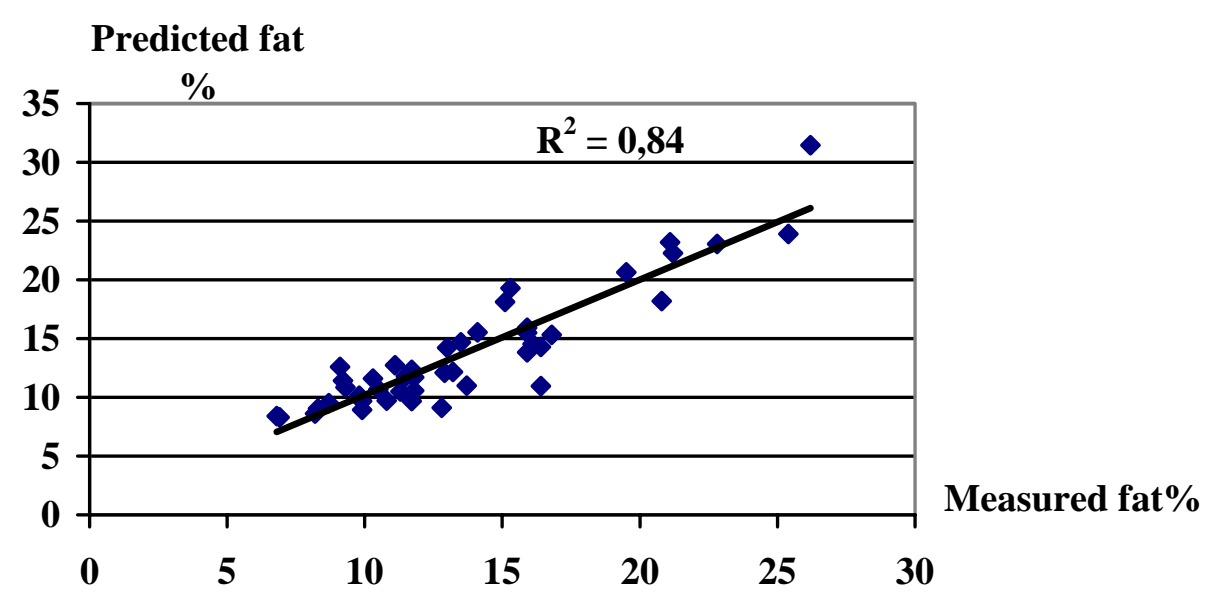

Fig. 12. Correlation between the predicted and the measured fat content $(\%)$ of chickens as determined by principal component analysis (Eq3 based on the abdominal region) (Korrelation zwischen dem erfaßten $(\%)$ und mit Hilfe der Hauptkomponentenanalyse (Eq3 von der abdominalen Region) geschätzten Fettgehalt der Tiere)

\section{Discussion}

Altogether 10-15 minutes were needed for the simultaneous whole-body scanning of three chickens. The 3D histograms developed clearly show the tissue composition of chicken bodies, with separate peaks corresponding to the breast- or thigh region. Based on the 3D surfaces, the fat deposition differences can be analyzed in the two sexes. In 
a similar manner, comparative investigations of the body composition were carried out on large bodied BUT and bronze type turkeys (ANDRÁSSY et al., 2003).

Not only the time, but also the costs of in vivo CT investigations can be significantly reduced when scanning only the abdominal region, without the considerable decrease in robustness of the prediction of fat content. The fat indices being independent of live weight seem to be applicable in the prediction of whole body crude fat content. Former experiments also proved the applicability of these index values, as the results strongly correlated with the crude fat content of the animal (ROMVÁRI et al., 2002). As the practical limit of this index is by $10 \% \mathrm{CF}$, and the chicken body contained the same fat amount over 4 weeks of age, the method worked well.

The correlations between the results of chemical analysis and pixel density data were strong enough to develop prediction equations. This methodology worked very well in case of fat content prediction, however, no adequate model could be achieved for protein. The robustness of the relationship between the calculated and chemically analyzed whole body CF content agrees with those reported by BENTSEN and SEHESTED (1989), SVIHUS and KATLE (1993) and ROMVÁRI et al. (1994) in chickens and also with those in other species (ROMVÁRI et al., 1998; ROMVÁRI et al., 2002). When testing the equations on an independent dataset, the relationship between the predicted and measured fat content was not worse. Especially the $\mathrm{R}^{2}$ value of 0.84 in case of the abdominal region proves the practical applicability of the method. In the authors opinion the applied method can effectively substitute the direct chemical analysis, especially as it is suitable for non invasive serial measurements of the same animal.

Fat content is one of the crucial quality traits also in broiler breeding. The good heritability of abdominal fat content $\left(\mathrm{h}^{2}=0.40,0.53,0.56\right.$ according to LEENSTRA, 1988; WANG et al., 1991; LE BIHAN-DUVAL, 2001) is a proper basis for the effective selection to lower it. The total body CF content investigated in the current study has a $0,53 \mathrm{~h}^{2}$ value according to Horn (1981). Furthermore, the strong relationship between the abdominal and total body fat content is also known (MAURUS et al., 1988). Based on the above-mentioned facts it would be worth expanding this non invasive method into selection procedures of broiler breeding.

\section{Acknowledgement}

This work was supported by the E. C. (Copernicus) as part of project CIPA-CT93-206.

\section{References}

ANDRÁSSY, G.; ROMVÁRI, R.; SÜTÖ, Z.; SZABÓ, A.; HORN, P.:

Comparative study of the body composition of different turkey genotypes by means of CT. Arch. Tierz., Dummerstorf 46 (2002) 3, 285-292

BENTSEN, H. B.; SEHESTED, E.:

Computerized tomography of chickens. Br. Poultry Sci., 30 (1989), 575-585

GREY, T.C.; ROBINSON, D.; JONES, J. M.:

Effect of age and sex on the eviscerated yield, muscle and edible offal of a commercial broiler strain. Br. Poultry Sci., 23 (1982), 289-298

HANCOCK, C.E.; BRADFORD, G.C.; EMMANS, G.C.; GOUS, R.M.:

The evaluation of the growth parameters of six strains of commercial broiler chickens. Br. Polutry Sci., 36 (1995), 247-264 
HAVENSTEIN, G.B.; FERKET, P.R.:

Estimated genetic changes in broiler growth, feed conversion and yield, 1991-2001. 11 ${ }^{\text {th }}$ European Poultry Conference, Bremen (2002). All abstracts with the full paper included CD of the $11^{\text {th }}$ EPC

HORN, P.; SÜTÖ, Z.; SØRENSEN, P.:

Growth, feed conversion and mortality of commercial meat type chicken during a twenty week growing

HORN, P.: period. Arch. f. Geflügelkunde, 62 (1998), 16-20

Handbook of polultry breeders.(In Hungarian) Mezõgazdasági Könyvkiadó, Budapest (1981), 697

KÖVÉR, G.; ROMVÁRI, R.; HORN, P.; BERÉNYI, E.; JENSEN, J.F.; SORENSEN, P.:

In vivo assessment of breast muscle, abdominal fat and total fat volume in meat type chickens by magnetic resonance imaging. Acta Vet. Hung. 46 (1998), 135-144

LE BIHAN-DUVAL, E. ; BERRI, C. ; BAEZA, E. ; MILLET, N. ; BEAUMONT, C.:

Estimation of the genetic parameters of meat characteristics and of their genetic correlations with growth and body composition in an experimental broiler line. Poultry Sci., 80 (2001),839-43

LEENSTRA, F.R.; PIT, R.:

Fat deposition in a broiler sire strain. 3. Heritability of and genetic correlations among body weight, abdominal fat and feed conversation. Poultry Sci., 67 (1988), 1-9

MAURUS, E. M.; KIRCHGEßNER, M.; ROTH, F.X.:

Beziehungen zwischen Teilstückanalysen und der Ganzkörperzusammensetzung bei Broilern. Arch. f. Geflügelkunde, 52 (1988), 261-267

MITCHELL, A.D.; ROSEBROUGH, R.W.; CONWAY, J.M.:

Body composition analysis of chickens by dual energy x-ray absortiometry. Poultry Sci., 76 (1997), 1746-1752

ROMVÁRI, R.; PERÉNYI, M.; HORN, P.:

In vivo measurement of total body fat content of broiler chickens by X-ray computerised tomography. Znan. Prak. Poljopr. Tehnol., 24 (1994), 215-220

ROMVÁRI, R.; SZENDRÕ, ZS.; JENSEN, J.F.; SORENSEN, P.; MILISITS, G.; BOGNER, P., HORN, P.; CSAPÓ, J.:

Noninvasive measurement of body composition of two rabbit populations between 6 - 16 week of age by computer tomography. J. Animal Breeding and Genetics, 115 (1998), 383-395

ROMVÁRI, R.; ANDRÁSSY- BAKA, G.;.REPA, I.; ZÁVODA, F.; SÜTÖ, Z.; HORN, P.: In vivo $3 \mathrm{D}$ evaluation of breast muscle of broiler chickens by means computer tomograph XXI World's Poultry congress (2000), Montreal, August 20-24, Proceedings CD 11-14

ROMVÁRI, R., HANCZ, CS., PETRÁSI, ZS., MOLNÁR, T., HORN P.:

Non-invasive measurement of fillet composition of four freshwater fish species by computer tomography. Aquaculture International, 10 (2002), 231-240

SØRENSEN, P.; DUCRO, J. B.:

Age related and proportional aspects of growth in broilers. Arch. f. Geflügelkunde, Sonderheft (1995), $30-34$

SAVORY, C. J.:

Effects of long- term selection for broiler traits. 11.European Poultry Conference, Bremen (2002) Abstract CD of the $11^{\text {th }}$ EPC

SÜTÖ, Z.; HORN, P.; SØRENSEN, P.; CSAPO, J.:

Carcass trait, abdominal fat deposition and chemical composition of commercial meat type chicken during a twenty week growing period. Arch. f. Geflügelkunde, 62 (1998), 21-25

SVIHUS, B.; KATLE, J.:

Computerised tomography as a tool to predict composition traits in broilers. Comparisons of results across samples and years. Acta Agriculturae Scandinavia. Animal Science, 43 (1993), 214-218

WANG, L.; CHAMBERS, J.R.; MCMILLAN, I.:

Heritabilities of adjusted and unadjusted feed and abdominal fat traits in a broiler dam population. Poultry Sci., 70 (1991), 440-446

Received: 2003-03-24

Accepted: 2003-09-29

Corresponding author

ROBERT ROMVARI, PhD.

Kaposvár University, Faculty of Animal Science

H-7400, Kaposvár, Guba S. U. 40. Hungary 